\title{
EFFECTIVENESS OF MACROPRUDENTIAL POLICIES IN DEVELOPING ASIA: AN EMPIRICAL ANALYSIS
}

Minsoo Lee, Ruben Carlo Asuncion, and Jungsuk Kim

NO. 439

July 2015
ADB ECONOMICS WORKING PAPER SERIES 
ADB Economics Working Paper Series

\section{Effectiveness of Macroprudential Policies in Developing Asia:} An Empirical Analysis

Minsoo Lee, Ruben Carlo Asuncion, and Jungsuk Kim

No. 439 | July 2015
Minsoo Lee(mlee@adb.org) is Senior Economist at the Economic Research and Regional Cooperation Department (ERCD), Asian Development Bank (ADB). Ruben Carlo Asuncion (carlo.asuncion@gmail.com) is a consultant at the ERCD, ADB. Jungsuk Kim (iias7@sogang.ac.kr) is a researcher at the Institute of International and Areas Studies, Sogang University. 
Asian Development Bank

6 ADB Avenue, Mandaluyong City

1550 Metro Manila, Philippines

www.adb.org

(C) 2015 by Asian Development Bank

July 2015

ISSN 2313-6537 (Print), 2313-6545 (e-ISSN)

Publication Stock No. WPS157507-2

The views expressed in this paper are those of the authors and do not necessarily reflect the views and policies of the Asian Development Bank (ADB) or its Board of Governors or the governments they represent.

ADB does not guarantee the accuracy of the data included in this publication and accepts no responsibility for any consequence of their use.

By making any designation of or reference to a particular territory or geographic area, or by using the term "country" in this document, $A D B$ does not intend to make any judgments as to the legal or other status of any territory or area.

Notes:

1. In this publication, "\$” refers to US dollars.

2. ADB recognizes "China" as the People's Republic of China and "Hong Kong" as Hong Kong, China.

The ADB Economics Working Paper Series is a forum for stimulating discussion and eliciting feedback on ongoing and recently completed research and policy studies undertaken by the Asian Development Bank (ADB) staff, consultants, or resource persons. The series deals with key economic and development problems, particularly those facing the Asia and Pacific region; as well as conceptual, analytical, or methodological issues relating to project/program economic analysis, and statistical data and measurement. The series aims to enhance the knowledge on Asia's development and policy challenges; strengthen analytical rigor and quality of ADB's country partnership strategies, and its subregional and country operations; and improve the quality and availability of statistical data and development indicators for monitoring development effectiveness.

The ADB Economics Working Paper Series is a quick-disseminating, informal publication whose titles could subsequently be revised for publication as articles in professional journals or chapters in books. The series is maintained by the Economic Research and Regional Cooperation Department. 


\section{CONTENTS}

TABLES AND FIGURES

ABSTRACT $v$ V

$\begin{array}{ll}\text { I. INTRODUCTION } & 1\end{array}$

II. MACROPRUDENTIAL POLICY: CONCEPTUAL BASIS AND LITERATURE REVIEW 1

III. EMPIRICAL METHODOLOGY AND DATA 4

IV. $\quad$ EMPIRICALRESULTS 6

A. People's Republic of China 6

B. Hong Kong, China $\quad 7$

C. Indonesia 9

D. India 10

E. Republic of Korea $\quad 11$

F. Malaysia $\quad 12$

G. Singapore $\quad 12$

H. Thailand 14

$\begin{array}{ll}\text { I. Taipei,China } & 14\end{array}$

J. Philippines 14

V. CONCLUDING OBSERVATIONS AND POLICYIMPLICATIONS

$\begin{array}{ll}\text { REFERENCES } & 17\end{array}$ 


\section{TABLES AND FIGURES}

\section{TABLES}

$1 \quad$ Conceptual Basis of Macroprudential Policy Instruments

2 Specific Use of Macroprudential Policy Instruments by Economy, 2000-2013

\section{FIGURES}

$1 \quad$ Latent Propensity to Macroprudential Policy Tightening in the People's Republic of China, 2000-2013

2 Credit-Related Macroprudential Policy Tightening in the People's Republic of China

3 Liquidity-Related Macroprudential Policy Tightening in the People's Republic of China

$4 \quad$ Credit-Related Macroprudential Policy Tightening in Indonesia

10 Liquidity-Related Macroprudential Policy Tightening in Indonesia

10

$6 \quad$ Credit-Related Macroprudential Policy Tightening in India

7 Credit-Related Macroprudential Policy Tightening in the Republic of Korea

8 Credit-Related Macroprudential Policy Tightening in Singapore 


\begin{abstract}
The global financial crisis highlighted the need for national bank supervisory authorities to improve surveillance systems and to detect early on the buildup of macroeconomic risks that could threaten the entire financial system. This paper presents an empirical framework for analyzing how effective macroprudential policies control credit growth, leverage growth, and housing price appreciation. Two significant findings emerge. Broadly, macroprudential policies can indeed promote financial stability in Asia. More specifically, different types of macroprudential policies are more effective against different types of macroeconomic risks.
\end{abstract}

Keywords: developing Asia, financial stability, macroprudential policy

JEL Classification: G01, G28, L51 


\section{INTRODUCTION}

Before the global financial crisis, financial regulation largely took the form of microprudential policies and centered on monitoring prudential risks to individual institutions. As such, financial regulation failed to consider the buildup of macroeconomic risks and vulnerabilities that could pose systemic risk by destabilizing a number of institutions simultaneously. The global financial crisis underlined an urgent need for financial regulatory authorities to identify and monitor early on the buildup of macroeconomic risks that could threaten the financial system. Such early detection and prevention requires strong macroprudential policy measures-for example, caps on the loan-to-value (LTV) ratio-designed to mitigate financial stability risks that stem from vulnerabilities building up in the broader financial system.

A macroprudential approach has two dimensions: a time dimension and a cross-sectional dimension (Borio 2010). In the time dimension, the source of system-wide distress can be the procyclicality of the financial system. That is, financial institutions and markets overexpose themselves to risks during an upswing in the financial cycle and then become overly risk averse during a downswing leaving the entire financial system and economy vulnerable to booms and busts. On the other hand, the cross-sectional dimension of systemic risk arises from the interconnectedness of financial institutions and markets that can result in joint vulnerabilities and failures of financial institutions, i.e. when the actions and problems of individuals or financial institutions have spillover effects on the overall financial system. Given their interconnectedness, the contemporary market-based finance sector should be thought of not only as the deposit-taking, loan-making activities of commercial banks but also as investment banks, money market funds, insurance firms, and other financial institutions.

This paper presents the basic framework of an empirical analysis to gauge how effectively macroprudential policies target credit-, liquidity-, and capital-related financial stability risks. The framework looks at the impact of three different types of macroprudential policies on three key indicators of financial stability: credit growth, leverage growth, and housing price escalation. We document the macroprudential tightening policies that 10 developing Asian economies have actually used.

An important innovation in this paper is to apply the qualitative vector autoregressive regression (Qual VAR) model to estimate the latent propensity to three types of macroprudential policy measures and then to generate the dynamic impulse responses of financial stability indicators with respect to the macroprudential policy measures. Overall, our results suggest that credit-related macroprudential policy instruments can effectively dampen credit expansion and housing price inflation while liquidity-related macroprudential policy tools moderate leverage growth and housing price escalation.

\section{MACROPRUDENTIAL POLICY: CONCEPTUAL BASIS AND LITERATURE REVIEW}

The Basel Committee on Banking Supervision is increasingly guided by the need for a macroprudential perspective on financial regulation in addition to the traditional microprudential perspective. Although progress has been made on the regulatory front-especially with Basel III tightening the rules on the quantity and quality of bank capital including the requirement of a countercyclical capital bufferregulations apply to only some financial institutions. In contrast, macroprudential policy aims to limit the buildup of risk in the entire financial system and to enhance its resilience following shocks. Efforts 
are geared mainly toward identifying systemic threats to financial markets that could affect the real economy and thus to preventing a financial crisis.

Macroprudential policy measures fall into the following three broad categories (Table 1): (i) credit controls including caps on ratios of LTV and of debt-to-income (DTI) and on foreign currency lending as well as ceilings on credit or credit growth; (ii) liquidity regulations that place limits on net open currency positions or currency mismatches and on maturity mismatches while establishing reserve requirements; and (iii) capital requirements including countercyclical capital requirements, time-varying and dynamic provisioning, and restrictions on profit distribution. Macroprudential tools such as minimum capital ratios and LTV ratios have been used for some time. Reserve requirements could provide liquidity cushions while dynamic provisioning could help build capital buffers during upturns. ${ }^{1}$

\section{Table 1: Conceptual Basis of Macroprudential Policy Instruments}

\begin{tabular}{|c|c|}
\hline Instruments & Conceptual Basis \\
\hline $\begin{array}{l}\text { 1) Caps on the loan-to- } \\
\text { value ratio (LTV) }\end{array}$ & $\begin{array}{l}\text { The LTV imposes a down payment constraint on household capacity to borrow. In theory, the } \\
\text { constraint limits the procyclicality of collateralized lending since housing prices and household } \\
\text { capacity to borrow based on the collateralized value of the house interact in a procyclical manner. } \\
\text { Set at an appropriate level, the LTV addresses systemic risk whether or not it is frequently } \\
\text { adjusted; however, the adjustment of the LTV makes it a more potent countercyclical policy } \\
\text { instrument. }\end{array}$ \\
\hline $\begin{array}{l}\text { 2) Caps on the debt-to- } \\
\text { income ratio (DTI) }\end{array}$ & $\begin{array}{l}\text { The DTI represents prudential regulation aimed at ensuring banks' asset quality when used alone. } \\
\text { When used in conjunction with the LTV, however, the DTI can help further dampen the cyclicality } \\
\text { of collateralized lending by adding another constraint on household capacity to borrow. As with } \\
\text { the LTV, adjustments in the DTI can be made in a countercyclical manner to address the time } \\
\text { dimension of systemic risk. }\end{array}$ \\
\hline $\begin{array}{l}\text { 3) Caps on foreign } \\
\text { currency lending }\end{array}$ & $\begin{array}{l}\text { Loans in foreign currency expose the unhedged borrower to foreign exchange risks which, in turn, } \\
\text { subject the lender to credit risks. The risks can become systemic if the common exposure is large. } \\
\text { Caps (or higher risk weights, deposit requirements, etc.) on foreign currency lending may be used } \\
\text { to address this foreign exchange induced systemic risk. }\end{array}$ \\
\hline $\begin{array}{l}\text { 4) Ceilings on } \\
\text { credit/Credit growth }\end{array}$ & $\begin{array}{l}\text { A ceiling may be imposed on either total bank lending or credit to a specific sector. The ceiling on } \\
\text { aggregate credit or credit growth may be used to dampen the credit/asset price cycle-the time } \\
\text { dimension of systemic risk. The ceiling on credit to a specific sector, such as real estate, may be } \\
\text { used to contain a specific type of asset price inflation or limit common exposure to a specific } \\
\text { risk-the cross-sectional dimension of systemic risk. }\end{array}$ \\
\hline $\begin{array}{l}\text { 5) Reserve } \\
\text { requirements }\end{array}$ & $\begin{array}{l}\text { This monetary policy tool may be used to address systemic risk in two senses. First, the reserve } \\
\text { requirement has a direct impact on credit growth, so it may be used to dampen the credit/asset } \\
\text { price cycle-the time dimension of systemic risk. Second, the required reserves provide a liquidity } \\
\text { cushion that may be used to alleviate a systemic liquidity crunch when the situation warrants. }\end{array}$ \\
\hline $\begin{array}{l}\text { 6) Countercyclical } \\
\text { capital requirements }\end{array}$ & $\begin{array}{l}\text { The requirement can take the form of a ratio or risk weights raised during an upturn as a restraint } \\
\text { on credit expansion and reduced during a downturn to provide a cushion so that banks do not } \\
\text { reduce assets to meet the capital requirement. A permanent capital buffer, which is built up during } \\
\text { an upturn and deleted during a downturn, serves the same purpose. Both can address the } \\
\text { cyclicality in risk weights under Basel II based on external ratings that are procyclical. }\end{array}$ \\
\hline
\end{tabular}

continued on next page

1 Other tools such as limits on profit redistribution could also have countercyclical buffer effects helping banks' willingness to maintain or at least reduce their balance sheets during recessions. More generally, there are reasons to doubt that these tools will usually be effective, particularly in economies that have fully liberalized capital accounts and otherwise quite liberal finance sectors. 
Table 1 continued

\begin{tabular}{|l|l|}
\hline Instruments & \multicolumn{1}{c|}{ Conceptual Basis } \\
\hline $\begin{array}{l}\text { 7) Time- } \\
\text { varying/Dynamic } \\
\text { provisioning }\end{array}$ & $\begin{array}{l}\text { Traditional dynamic provisioning is calibrated on historical bank-specific losses, but it can also be } \\
\text { used to dampen the cyclicality in the financial system. The provisioning requirement can be raised } \\
\text { during an upturn to build a buffer and limit credit expansion and lowered during a downturn to } \\
\text { support bank lending. It may be adjusted either according to a fixed formula or at the discretion of } \\
\text { the policy maker to affect bank lending behavior in a countercyclical manner. }\end{array}$ \\
\hline $\begin{array}{l}\text { 8) Restrictions on profit } \\
\text { distribution }\end{array}$ & $\begin{array}{l}\text { These prudential regulation requirements are intended to ensure the capital adequacy of banks. } \\
\text { Since undistributed profits are added to bank capital, the restrictions tend to have a } \\
\text { countercyclical effect on bank lending if used in a downturn. The capital conservation buffer of } \\
\text { Basel III has a similar role. }\end{array}$ \\
\hline $\begin{array}{l}\text { 9) Limits on net open } \\
\text { positions/Currency } \\
\text { mismatch }\end{array}$ & $\begin{array}{l}\text { Such prudential regulation tools limit banks' common exposure to foreign currency risks. In } \\
\text { addition, the limits may be used to address an externality-sharp exchange rate fluctuations } \\
\text { caused by a convergence of purchases/sales of foreign exchange by banks. This externality } \\
\text { increases the credit risk of unhedged borrowers with heavy foreign currency debt. }\end{array}$ \\
\hline $\begin{array}{l}\text { 10) Limits on maturity } \\
\text { mismatch }\end{array}$ & $\begin{array}{l}\text { These prudential regulation tools may be used to address systemic risk since the choice of } \\
\text { asset/liability maturity creates an externality-fire sales of assets. In a crisis, the inability of a } \\
\text { financial institution to meet its short-term obligations due to maturity mismatches may force it to } \\
\text { liquidate assets thus imposing a fire sale cost on the rest of the financial system. The funding } \\
\text { shortages of a few institutions could also result in a systemic liquidity crisis due to the contagion } \\
\text { effect. }\end{array}$ \\
\hline
\end{tabular}

Source: Lim et al. 2011, Appendix VI, p. 72.

The greater attention to macroprudential policy is evident in both advanced and developing economies. Compared with other regions, developing Asia has a lot of experience in implementing a variety of macroprudential measures consisting of credit-related, liquidity-related, and capital-related policy instruments to prevent or to address asset price bubbles and other threats to financial stability. This experience is derived primarily from dealing with previous threats to financial stability, especially arising from volatile capital flows. Since 2000 and partly in response to the Asian financial crisis of 1997, in order to cope with potentially volatile, large-scale capital inflows, macroprudential measures have been widely used in developing Asia.

While advanced economies seldom used macroprudential policies during the 1990s, they implemented many of these tools after the global financial crisis as part of a broader trend toward more stringent financial regulation. Moreover, major advanced economies have recently established regulatory frameworks for macroprudential policy. Since the global economy began to recover from the global crisis, many economies in developing Asia have been actively using macroprudential policy to deflate potential bubbles in the property and equity markets. Risks had accumulated during the period of high growth and low inflation, particularly in real estate-related sectors.

Recent literature on financial crises has centered on explaining how leveraging in financial markets causes bubbles and influences economic activity. Measures of economy-wide financial activity such as deviations from the long-run trend of the credit-to-gross domestic product (GDP) ratio are considered to be informative and potential guides for macroprudential policy. There are a number of empirical studies on macroprudential policy, but little empirical evidence exists on its effectiveness, most notably as to which policies work best in a country-specific context. Quantifying the effectiveness of macroprudential policy is challenging because it involves a multitude of instruments with inconsistent intervals and frequencies targeting different segments of the financial system (Tillmann 2014) which complicates standard empirical analysis. Some papers have analyzed the effects of macroprudential policy on various measures of financial vulnerability and stability (IMF 2012, 2013a, and 2013b). Lim et al. (2011) reviewed the use of key macroprudential instruments in 46 economies up to 2010 and estimated the effectiveness of tightening individual instruments in reducing 
the procyclicality of financial risks. They concluded that many of the frequently used macroprudential instruments have been effective in lowering systemic risks.

The main contribution from applying modern versions of dynamic stochastic general equilibrium (DSGE) models to financial-real linkages lies in explaining the mechanisms through which real and financial factors interact and how this interaction can generate systemic risks. In particular, the combination of a macroeconomic boom, a credit boom, and low interest rates can provoke a crisis when the credit boom turns supply driven (Boissay, Collard, and Smets 2013). Christensen, Meh, and Moran (2011) examine countercyclical capital ratio requirements; and Christensen and Meh (2011); Gelain, Lansing, and Mendicin (2013); and Walentin (2014) derive models for setting up a countercyclical LTV ratio based on a specific feedback rule. Crowe et al. (2011) delve into a timevarying LTV regulation, and Funke and Paetz (2013) and Wong et al. (2011) both estimate a DSGE model specifically for Hong Kong, China.

Aiyar, Calomiris, and Wieladek (2012) examined the effect that the time-varying minimum capital requirement introduced in the United Kingdom (UK) had on credit growth and also investigated the degree of regulatory arbitrage resulting from the introduction of new regulations. Alberola, Trucharte, and Vega (2011) investigated dynamic provisioning in Spain. Although they typically found that a countercyclical LTV ratio can moderate housing price volatility and credit growth, their results were calibrated from a set of linearized equilibrium conditions that are of limited value in understanding the buildup of housing price bubbles (Tillmann 2014). Furthermore, some of these models depend on extreme simplification of the banking sector that makes them too abstract for policy-oriented analysis (Kawata et al. 2012).

Another strand of literature exploits information on various policy actions to explain asset price movements and credit growth by conducting event studies or by coding policy episodes with a binary indicator. This strand employs a set of standard macroeconomic control variables to examine the impact of macroprudential policy instruments on housing price escalation and credit growth. Claessens, Gosh, and Mihet (2013) examined the effectiveness of different macroprudential policies aimed at banking system vulnerabilities. Their regression results showed that measures such as caps on DTI and LTV as well as limits on credit growth and foreign currency lending are effective in reducing leverage, asset, and noncore to core liabilities growth during booms. They also suggest that macroprudential policies are much more effective in booms than in busts, implying the presence of asymmetric effects.

\section{EMPIRICAL METHODOLOGY AND DATA}

In theory, macroprudential measures can safeguard the stability of the banking system and of the broader financial system by mitigating risks that affect the entire financial system and therefore the economy. The question is, as always, whether they actually work in practice. This section presents the broad contours of the methodology and data along with the basic framework of an empirical analysis to gauge how effectively macroprudential policies control credit growth, leverage growth, and housing price appreciation.

A major innovation of this analysis is defining macroprudential policy as a continuous variable rather than as a binary variable. Tillmann (2014) and Meinusch and Tillmann (2014) recently extended a multivariate dynamic probit model - the Qual VAR model that Dueker (2005) originally applied to forecast business cycle turning points-to uncover the latent propensity to macroprudential policy 
tightening from observed binary policy data. This modified methodology can examine the dynamic effectiveness of macroprudential policy and unconventional monetary policy by addressing the exogenous treatment of binary macroprudential policy indicators that are likely endogenous and by tracing out the dynamic adjustment of the endogenous variables following different macroprudential policy shocks.

The binary macroprudential policy indicators often do not properly represent a policy stance that leans toward tightening, easing, or maintaining a neutral stance. One advantage of using the Qual VAR is to uncover latent and unobservable propensity for macroprudential tightening from observed binary policy data that provide an endogenous continuous series reflecting the business cycle. A standard VAR with the generated latent series can provide estimates and dynamic impulse response functions for macroprudential policy shocks.

Following Tillmann (2014) and Meinusch and Tillmann (2014), suppose we identify a binary dependent variable $y_{t} \in\{0,1\}$, which is driven by a continuous latent variable $y^{*}$

with

$$
y_{t}=\left\{\begin{array}{l}
0 \text { if } y_{t}^{*} \leq 0 \\
1 \text { if } y_{t}^{*}>0
\end{array}\right.
$$

$$
y_{t}^{*}=\rho y_{t-1}^{*}+\mathbf{X}_{t-1} \beta+\epsilon_{t,} \quad \epsilon_{t} \sim \mathcal{N}(0,1),
$$

where $\mathbf{X}_{t-1}$ is a set of lagged explanatory variables such as the growth rate of real GDP, the change in the short-term interest rate, the growth rate of real credit, and changes in real housing prices.

Equation (2) is dynamic in the sense that the latent variable setting to determine macroprudential policy displays autoregressive properties. A Qual VAR incorporates this equation in a VAR system of the $\mathbf{X}_{t}$ vector. The Qual VAR model with $k$ endogenous variables and $p$ lags can now be represented as

where

$$
\boldsymbol{\Phi}(L) \mathbf{Y}_{t}=\mu+\epsilon_{t}
$$

$$
\mathbf{Y}_{t}=\left(\begin{array}{l}
\mathbf{X}_{t} \\
y_{t}^{*}
\end{array}\right)
$$

consists of macroeconomic data $\mathbf{X}_{t}$, and the latent variable $y_{t}^{*}$.

The Qual VAR estimation is continuous with the use of a Markov Chain Monte Carlo (MCMC) method, a class of algorithms for sampling from probability distributions that are based on the Markov chain that has a desired distribution as its equilibrium distribution. Three crucial assumptions are made. First, the VAR coefficients $\boldsymbol{\Phi}$ are normally distributed with the mean and the variance given by the ordinary least squares (OLS) estimates. Second, an inverted Wishart distribution, a generalization to multiple dimensions of the Chi-square distribution, is assumed for the covariance matrix $\boldsymbol{\Sigma}$. Lastly, the latent variable $y^{*}$ that is required to be positive whenever $y_{t}$ is equal to 1 is assumed to follow a truncated normal distribution. Given $y^{*}$, the conditional distribution of the VAR coefficients is given by the OLS estimates. Since neither of the latter two conditioning assumptions mentioned holds, the MCMC estimation is used. When sufficient numbers of iterations are executed, as those of Dueker (2005) and Tillmann (2014), a draw from either conditional distribution can be seen as a draw from the joint posterior distribution. 
The Qual VAR is estimated over a sample period from the first quarter (Q1) of 2000 to the fourth quarter (Q4) of 2013. The vector $\mathbf{X}_{t}$ consists of the growth rate of real GDP to proxy for the state of the economy's business cycle, the change in interest rates to control for the monetary policy stance that can affect the effectiveness of policies and its financial cycle, the growth rate of real credit, and the change in real housing prices. Data came from varied sources such as the International Monetary Fund's (IMF) International Financial Statistics, CEIC Data Company, the Bank for International Settlements (BIS), the Economist Intelligence Unit, and other central bank sources. A database of macroprudential policy instruments draws from Lim et al. (2011, 2013); Shim et al. (2013); Zhang and Zoli (2013); documents posted on the websites of central banks such as annual reports and financial stability reports; the Annual Report on Exchange Arrangements and Exchange Restrictions database; and research papers on macroprudential policy in individual economies and the region. The Consumer Price Index (CPI) was used to deflate nominal variables. Leverage was also used and is measured as assets over equity obtained from CEIC Data Company. GDPs, the CPI, interest rates, and credit came from International Financial Statistics and the BIS.

\section{EMPIRICAL RESULTS}

Table 2 shows information about the macroprudential instruments that 10 economies have most actively applied in developing Asia during the sample period. In the sample, credit-related macroprudential policy instruments such as ratios of LTV and of DTI were used most frequently in Indonesia, the Republic of Korea, Singapore, and Thailand while liquidity-related macroprudential policy instruments such as reserve requirements and limits on net open currency positions were employed most commonly in the People's Republic of China (PRC), India, and the Philippines. Capitalrelated macroprudential policy tools were rarely applied except in India. The tools implemented most often were credit-related macroprudential policy measures.

Table 2: Specific Use of Macroprudential Policy Instruments by Economy, 2000-2013

\begin{tabular}{|c|c|c|c|c|c|c|c|c|c|c|c|c|}
\hline \multirow{2}{*}{ MPP type } & \multicolumn{10}{|c|}{ Economy } & \multirow{2}{*}{ Total } & \multirow{2}{*}{$\%$} \\
\hline & SIN & HKG & INO & MAL & KOR & IND & TAP & THA & $\mathrm{PHI}$ & PRC & & \\
\hline Credit-related $^{a}$ & 13 & 5 & 11 & 6 & 23 & 6 & 3 & 15 & 1 & 9 & 92 & 49.2 \\
\hline Liquidity-related $^{b}$ & 0 & 0 & 7 & 3 & 3 & 18 & 6 & 1 & 10 & 31 & 79 & 42.2 \\
\hline Capital-related $^{c}$ & 1 & 1 & 1 & 0 & 2 & 4 & 0 & 0 & 6 & 1 & 16 & 8.6 \\
\hline Total & 14 & 6 & 19 & 9 & 28 & 28 & 9 & 16 & 17 & 41 & 187 & 100.0 \\
\hline
\end{tabular}

PRC = People's Republic of China; HKG = Hong Kong, China; IND = India; INO = Indonesia; $\mathrm{KOR}=$ Republic of Korea; MAL = Malaysia; MPP = macroprudential policy; PHI = Philippines; $\mathrm{SIN}=$ Singapore; TAP = Taipei, China; $\mathrm{THA}=$ Thailand.

Notes:

${ }^{a}$ Caps on loan-to-value ratio, caps on debt-to-income ratio, caps on foreign currency lending, and ceiling on credit/credit growth

${ }^{b}$ Limits on net open currency positions/currency mismatch (NOP), limits on maturity mismatch, and reserve requirements

${ }^{c}$ Countercyclical/time-varying capital requirements, time-varying/dynamic provisioning, and restrictions on profit distribution Source: Authors' calculations.

\section{A. People's Republic of China}

Among the 10 developing Asian economies studied in this paper, the PRC authorities most frequently implemented macroprudential policies to address systemic risk from Q1 2000 to Q4 2013. The latent propensity to macroprudential policy tightening uncovered by the Qual VAR reflects the 
People's Bank of China's frequent use of macroprudential policies between Q1 2006 and Q2 2008 (Figure 1). The policy instruments were implemented to regulate financial institutions' liabilities and to curb the credit boom and housing price escalation and at the same time to avoid cross-sectional dimension systemic risk.

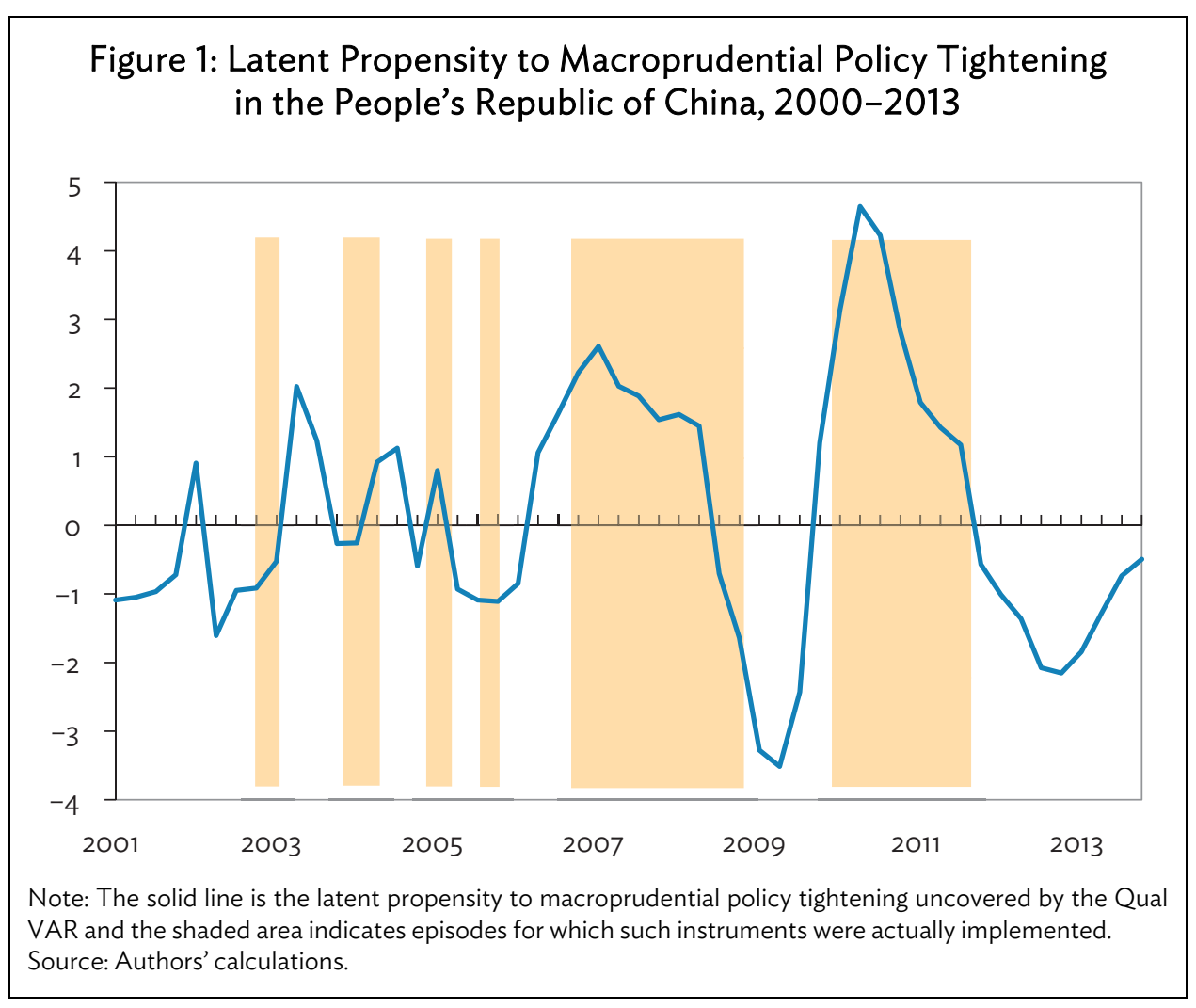

The People's Bank of China and the China Banking Regulatory Commission launched macroprudential instruments simultaneously to improve financial stability. They tightened macroprudential measures more than 40 times; at least 31 were liquidity-related instruments including reserve requirements.

The results show that credit-related macroprudential tightening immediately dampened credit expansion and reduced housing price appreciation with lags, but it had no effect on leverage growth (Figure 2). On the other hand, liquidity-related macroprudential tightening had an initial effect on reducing leverage, but the impact on housing price inflation occurred starting in the second period (Figure 3).

\section{B. Hong Kong, China}

Housing prices in Hong Kong, China have increased steeply since early 2009 with the level in 2013 more than double that in 2009. This rapid rise in residential real estate prices was attributed both to low interest rates and to the very tight housing supply. 


\section{Figure 2: Credit-Related Macroprudential Policy Tightening in the People's Republic of China}
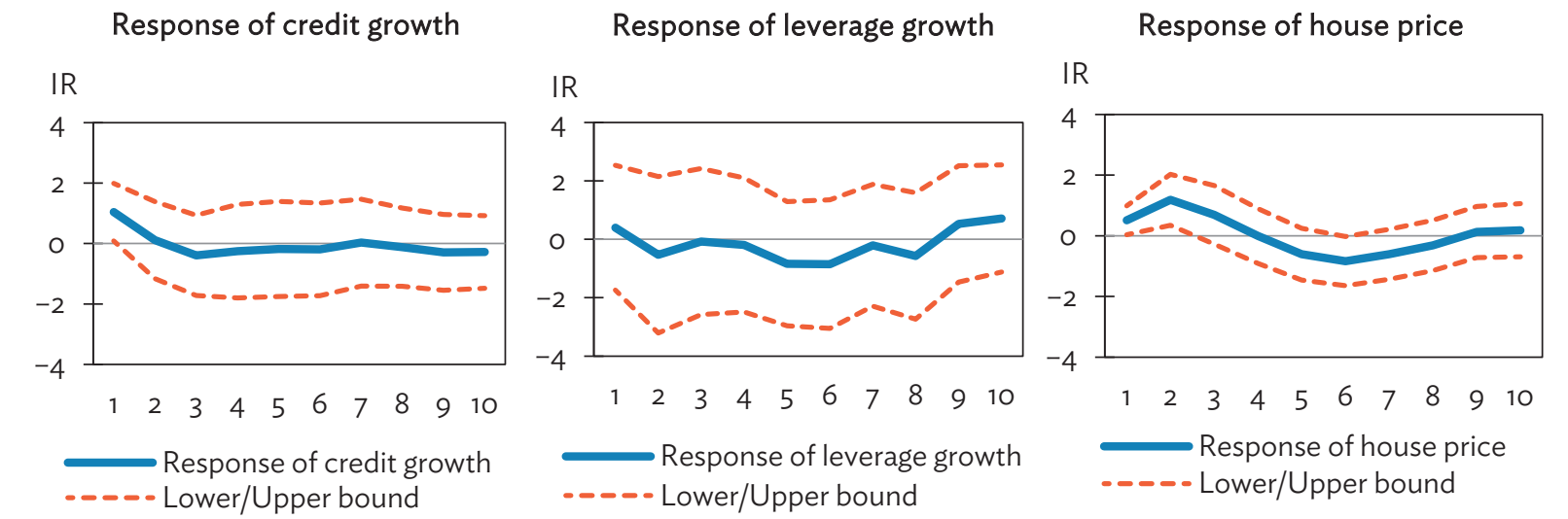

$\mathrm{IR}=$ impulse response

Source: Authors' calculations.

\section{Figure 3: Liquidity-Related Macroprudential Policy Tightening in the People's Republic of China}
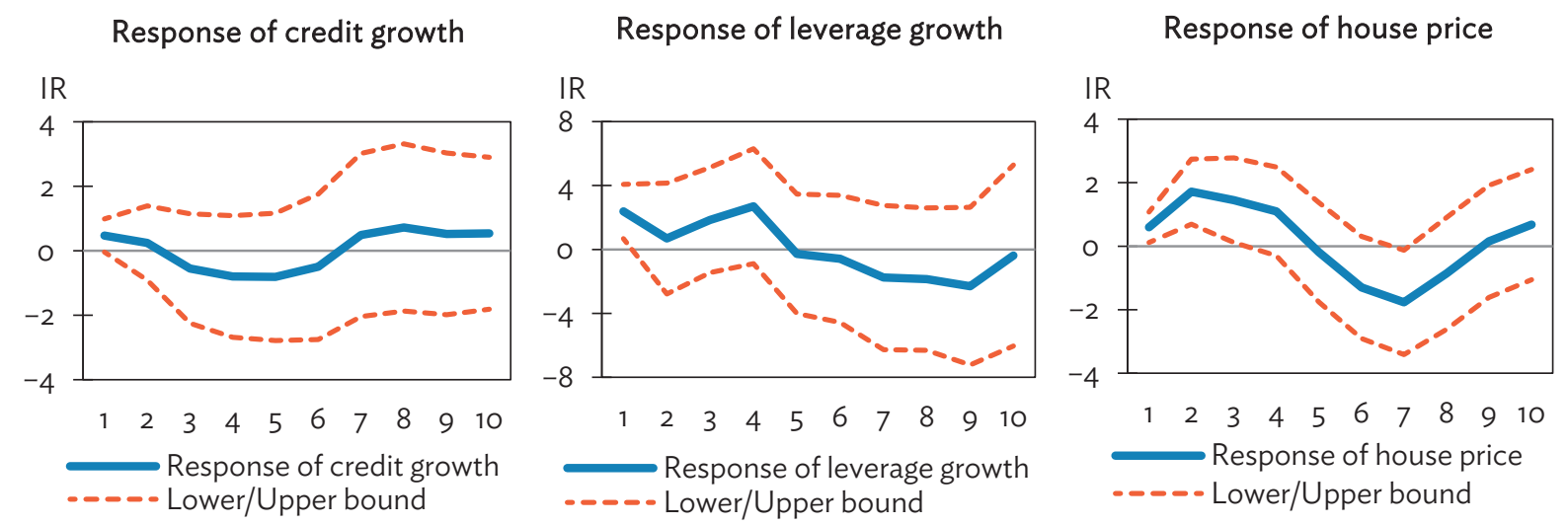

$\mathrm{IR}=$ impulse response.

Source: Authors' calculations.

The possibility of a housing-market bubble has been the most important financial stability concern for the Hong Kong Monetary Authority (HKMA) in the past several years. ${ }^{2}$ In November 2010, the government introduced a special stamp duty of as much as 15\% for properties resold within 2 years; in October 2012, it raised the rate to as much as 20\% and covered properties resold within 3 years. It also introduced a 15\% buyer's stamp duty on residential properties acquired by companies and

2 Over the past 2 decades, the HKMA has used limits on the LTV ratio as one type of targeted policy tool to manage banks' credit exposures to the property market and to lean against the amplitude of property price cycles. In the 1990s, a maximum LTV ratio of $70 \%$ was applied to all property types, then more differentiated ratios were introduced over time, depending on the property type and its value. 
nonlocals, which had accounted for about $20 \%$ of total transactions. ${ }^{3}$ Policy instruments such as caps on LTV ratios should be aimed at targeting leverage, credit growth, or property prices.

The empirical results support that the dampening effect of LTV policies on property prices is more apparent than its effect on leverage and credit growth. Higher transaction taxes with stamp duties levied by the government appear to be effective in constraining housing demand and in restraining housing price growth; however, the dampening effects of LTV and tax policies on housing prices and transaction volumes seem to be short-lived and negligible in Hong Kong, China.

\section{Indonesia}

Policy makers in Indonesia face a complex challenge in managing strong domestic demand in an uncertain global economic and financial environment. The key question is how to balance price stability for sustainable growth while maintaining external and financial system stability in the face of highly volatile capital flows, exchange rates, and global commodity prices. This tripartite nature of the macroeconomic challenge calls for efficient coordination to avoid conflicts between policies that might weaken domestic demand. In such circumstances, monetary policy alone would not be sufficient to pursue not only price stability but also financial system stability. Therefore, a mix of macroprudential policy and other macroeconomic policies has been stressed to deal with the multiple challenges in preserving monetary and financial system stability.

Macroprudential measures along with monetary and exchange rate policies have been frequently implemented since 2009. ${ }^{4}$ The latent propensity to macroprudential tightening reflects policy makers' responses to the Lehman collapse and the subsequent repercussions posed by the shift in allocating capital from advanced economies to Indonesia from the beginning of 2009 through 2011 (Bank of Indonesia 2004, 2009, and 2010). These macroprudential policy tools targeting credit growth were significantly effective in dampening the credit boom. Credit-related macroprudential tightening measures had an immediate effect on credit expansion while they had a lagged impact on leverage growth in Q3 (Figure 4). On the other hand, liquidity-related macroprudential tightening measures had no effect on dampening housing prices, but they had an instantaneous effect on credit expansion with a lagged impact on leverage growth in Q4 after the initial shock (Figure 5).

3 In February 2013, the government doubled the rates of existing ad valorem stamp duties for transactions for all types of properties except for local individuals who did not own any other residential property in Hong Kong, China at the time of acquisition. That seemed to have helped to moderate housing price inflation for a short period only. Elevated valuations at historically high levels indicate that it is premature to conclude that the risk of a collapse in housing prices has been averted.

4 In 2010, the rupiah reserve requirement was increased from 5\% to $8 \%$ to absorb domestic liquidity and to enhance the liquidity management of the banks without exerting a negative impact on the lending needed to stimulate growth. In 2012 , authorities introduced LTV ratio for lending for automobiles and property and also tightened standards for credit cards to reduce excessive lending to these sectors while maintaining overall lending growth consistent with the macroeconomic outlook. 

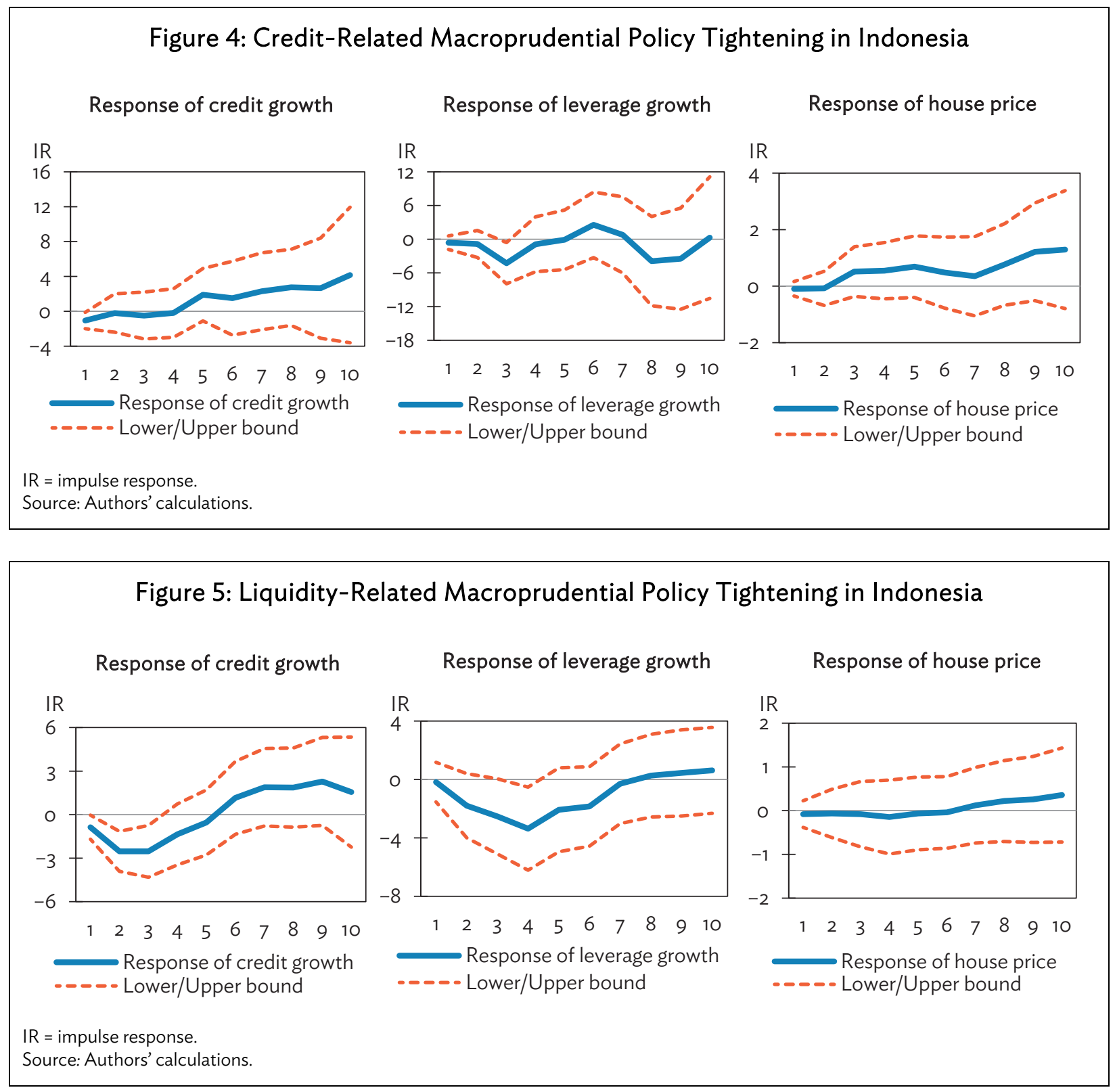

D. India

Aggregate bank credit growth has been an important monitor in the conduct of monetary and macroprudential policies. The Reserve Bank of India (RBI) has been using various macroprudential polices, including capital-related policies, since 2004 as a toolkit for ensuring financial stability. Leverage growth and housing price inflation could be marginally affected by implementing creditrelated macroprudential measures; however, credit tends to continue to grow. The impacts of liquidity-related measures appear to be marginally effective in curbing credit growth but significantly effective in impacting housing price escalation. 
RBI's capital-related macroprudential policies have focused on banks, and applying countercyclical policies to the shadow banking system ${ }^{5}$ has been challenging. Time-varying risk weights and provisioning norms on standard assets for certain specific sectors wherein excessive credit growth in conjunction with a sharp rise in asset prices have caused apprehension about a potential build-up of systemic risk and about asset bubbles. Those capital-related policies targeting credit expansion had the desired effect of moderating the credit boom in particular (Figure 6).

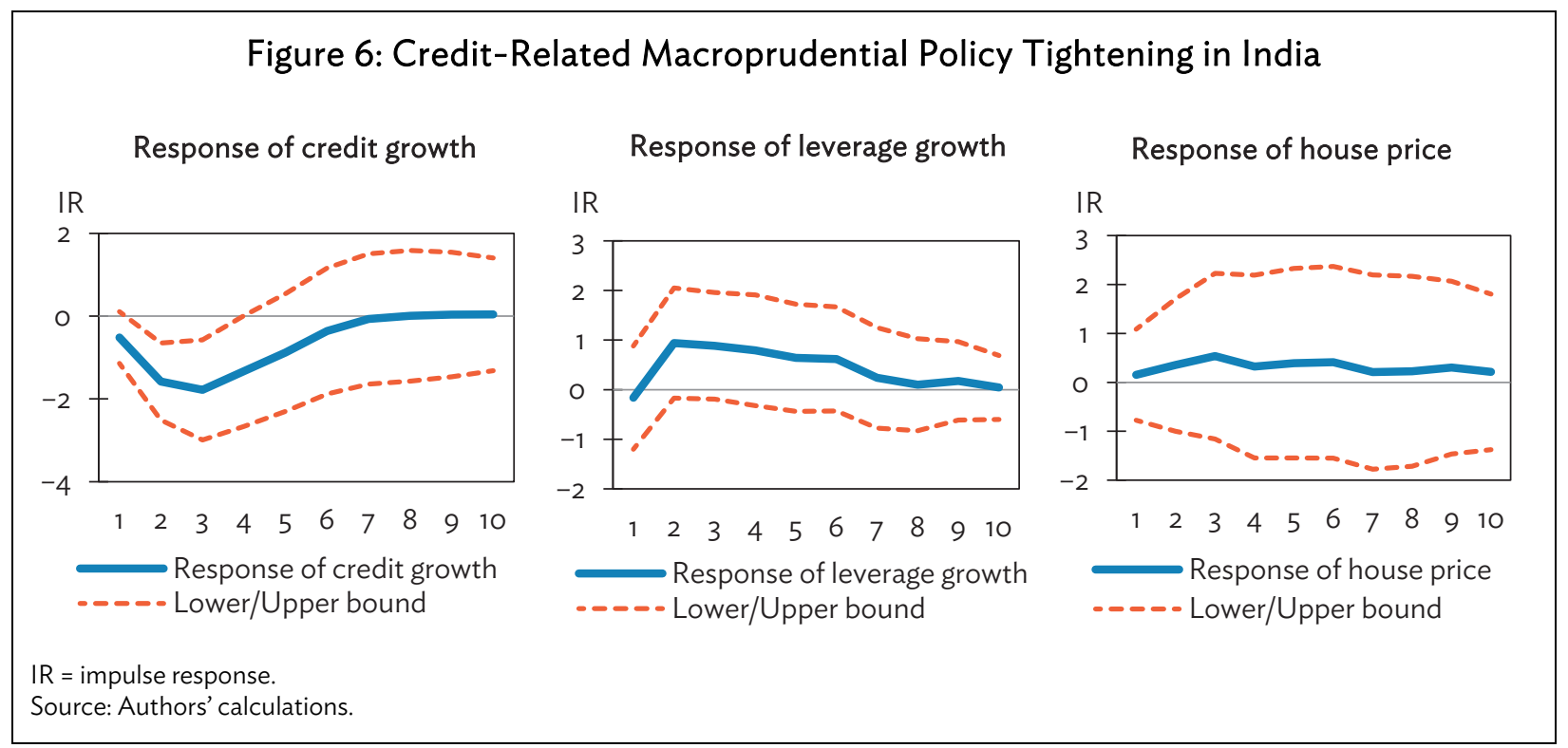

\section{E. Republic of Korea}

The Republic of Korea had systematically enacted several macroprudential policy instruments prior to the financial crisis in 2008 . From as early as 1997, several types of liquidity ratio regulations designed to cure the potential weaknesses in domestic banking and foreign currency transactions were in effect. ${ }^{6}$ Nevertheless, another round of crisis-like events hit the country in 2008. In fact, there was a new type of financial imbalance in domestic banking as well as in foreign exchange transactions associated in part with the housing market boom. To meet the growing demand for foreign exchange derivative transactions, banks had begun to rely on short-term foreign borrowings. ${ }^{7}$ The macroprudential policy tightened in 2006 and 2007 when housing prices hit a peak and then eased after the 2008 Lehman collapse. From 2000 to 2013, policy makers implemented macroprudential measures on 28 occasions, mostly credit-related instruments. The impact of credit-related macroprudential tightening ${ }^{8}$ showed a $^{2}$ lagged decline for housing price inflation until the second period and an immediate decline in leverage growth. Also, the instruments had an instantaneous impact on dampening credit expansion with a sustained effect of at most four periods after the initial shock (Figure 7).

5 the nonbanking financial companies

6 Later, with a housing boom becoming apparent, government authorities introduced limits on the LTV and DTI ratios in order to stabilize housing prices.

7 The situation of the Republic of Korea in the 2000s provides a basis for evaluating several macroprudential measures from various viewpoints. The choices of options - such as single versus multiple measures, broad-based versus targeted risks, or fixed versus time-varying applications - can also impact macroprudential policy effectiveness (Lim et al. 2011).

8 In 2011, authorities imposed a levy of up to $0.2 \%$ on bank noncore financial liabilities to manage speculative inflows of foreign capital (IMF 2012). 
Figure 7: Credit-Related Macroprudential Policy Tightening in the Republic of Korea

Response of credit growth

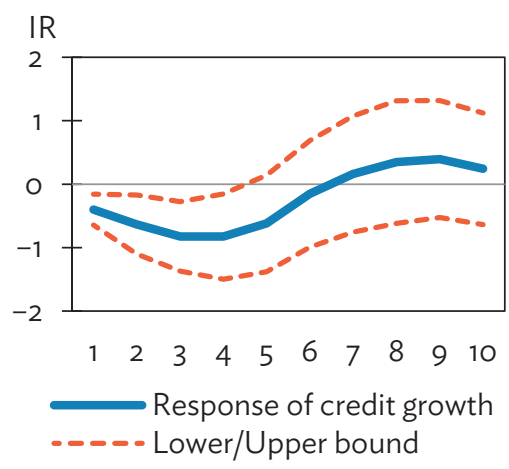

Response of leverage growth

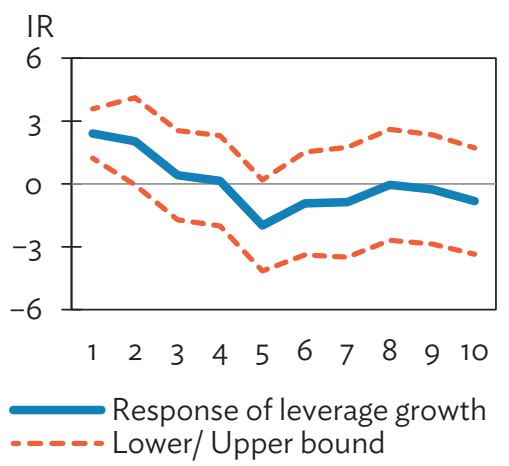

Response of house price

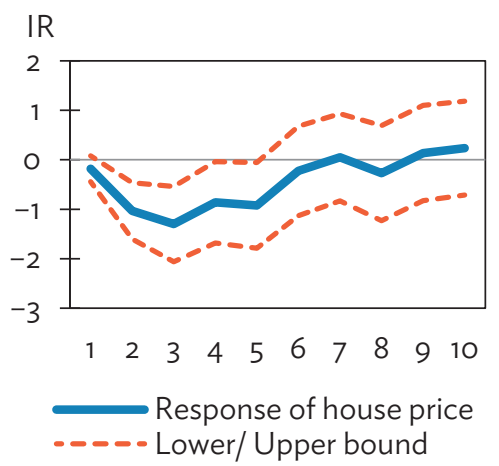

$\mathrm{IR}=$ impulse response.

Source: Authors' calculations.

\section{F. Malaysia}

In order to mitigate excessive investment and speculative activity in the property market and to contain substantial increases in property prices, in Q4 2010 Bank Negara Malaysia (BNM) introduced a maximum LTV ratio of $70 \%$ for loans to purchase third houses. In the following quarter, BNM imposed risk weights from $75 \%$ to $100 \%$ to strengthen banks' resilience against risky portfolios for loans with an LTV ratio of over $90 \%$ that had been approved and disbursed on or after 1 February $2011 .{ }^{9}$

The latent propensity to macroprudential tightening illustrates policy makers' strong intention to implement measures during 2010 and 2011. Specifically, in 2004, there were notable shocks to the global economy that contributed to inflationary pressures prompting BNM toward tightening measures. Amidst the Lehman collapse, BNM focused on easing measures in 2008 and early 2009. The divergence in growth performance and consequent differences in policy responses in both the advanced and emerging economies had important implications for global capital flows, asset prices, and exchange rates in 2010 prompting Malaysia to address upward pressure on its exchange rates and asset prices. The unexpected credit-related macroprudential policy tightening had an immediate lessening impact on the housing price boom and a marginally significant effect on credit and leverage growth, and liquidity-related macroprudential instruments had an instant impact on credit growth and a marginally significant effect on dampening leverage and housing price expansion.

\section{G. Singapore}

Although the highly developed financial system of Singapore is well-regulated and supervised by the Monetary Authority of Singapore (MAS), some risks to financial stability have emerged in recent years stemming from galloping real estate prices that have now surpassed their 2008 peak. There is concern that these price trends could rekindle inflation expectations and threaten financial stability, especially as the property boom is financed by easy credit. Property loans continue to grow at an elevated rate,

9 BNM raised the reserve requirement ratio by 1 percentage point per quarter from $1 \%$ in Q1 2011 to $4 \%$ in Q3 of that year. In 2012, the government issued Guidelines on Responsible Financing to promote prudent, responsible, and transparent retail financing practices as well as to ensure that the household sector and credit market remained resilient. 
and household debt increased rapidly for 3 years and reached 76\% of GDP at the end of 2012 with a corresponding increase in the exposure of locally incorporated banks to the property sector. The authorities have continued to respond proactively to new sources of systemic risk as they emerge, they have enhanced their surveillance and analytical frameworks for assessing the likelihood and impact of emerging systemic risks, and they have designed new policy instruments to effectively respond to such risks. ${ }^{10}$ The bank resolution framework should also be strengthened by enhancing the operational independence of the resolution agency and by allowing speedy and decisive action by MAS to address bank fragility.

Most recently, Singapore has tightened the limit on the ratio of mortgage service to income, capped the LTV ratio, imposed an additional buyer's stamp duty and increased the minimum cash down payment. These measures have largely targeted the more speculative segments of the market, but further tightening has been recommended on the segment owned mainly by foreigners and permanent residents.

The measures have been broadly successful. Housing price inflation has moderated recently, and housing affordability metrics remain contained." The effectiveness of macroprudential policies can be influenced by the degree of international financial integration. Singapore's highly developed and globally interconnected financial system with a large foreign bank presence makes it harder to prevent the circumvention of some macroprudential policies, but most measures have focused primarily on the property market that brought substantial dampening effects on housing prices and credit expansion with minimal impact on leverage growth (Figure 8).

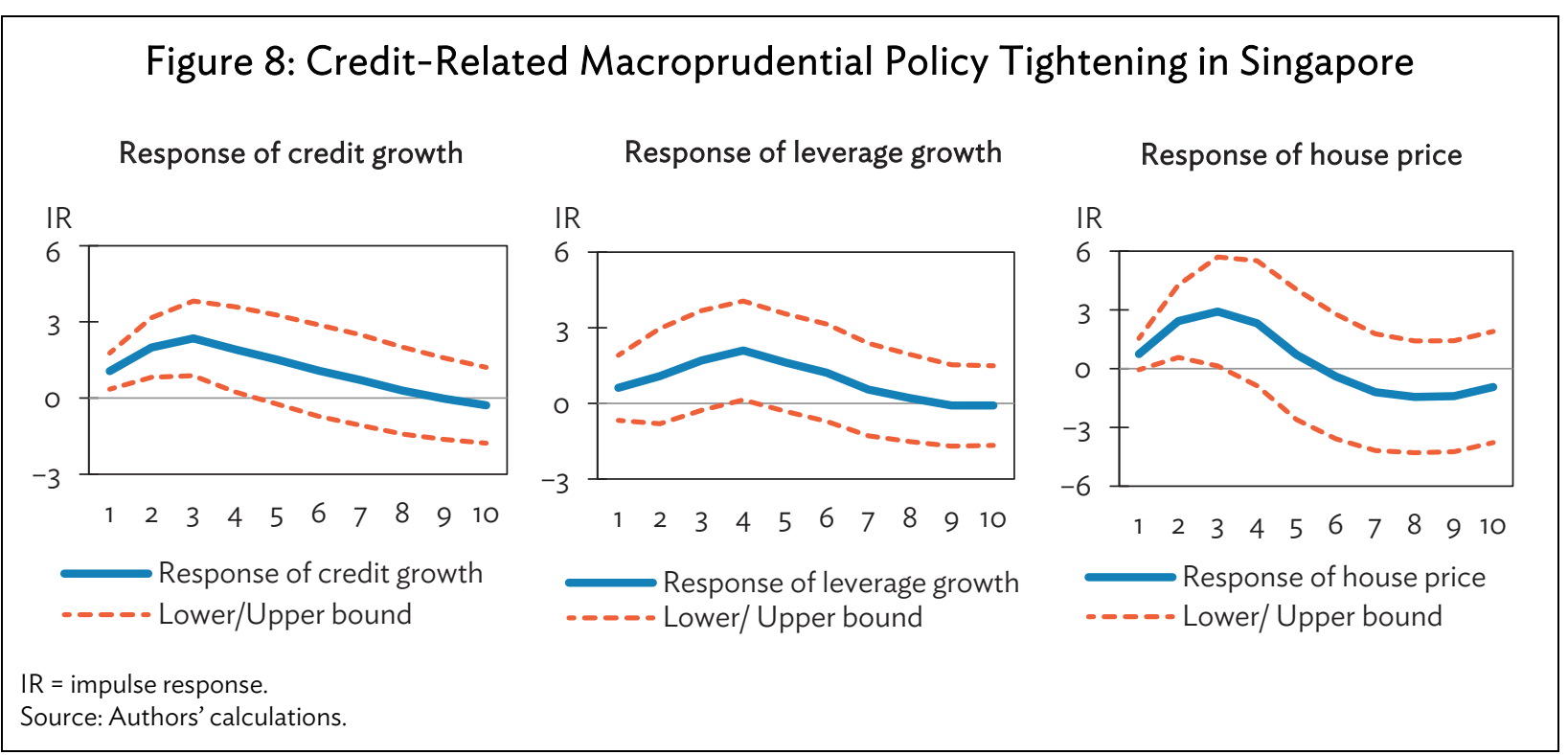

10 The International Monetary Fund's Financial Sector Assessment Program for Singapore conducted in November 2013 recommended that Singapore enhance its existing supervisory and regulatory frameworks, further develop its crisis management arrangements, and remain vigilant over credit growth.

1 Moreover, MAS required Singapore-incorporated banks to meet the Basel III minimum standards by 1 January 2013 ahead of the January 2015 timeline. Taking into account the capital conservation buffer requirement of 2.5\%, Singaporeincorporated banks should maintain at least $9 \%$ common equity tier 1 compared to the Basel III minimum of $7 \%$. 


\section{H. Thailand}

The latent tendency to macroprudential tightening such as limits on net open currency positions, the LTV ratio, capital surcharges, and reserve requirements depicts the Bank of Thailand's reaction to the instability brought about by uncertainty domestically and internationally that diminished investor confidence to a certain extent. In 2010, various negative factors affected Thailand's economic performance and contributed to macroprudential tightening including uncertainties about the global economic recovery after 2008, domestic political unrest, exchange rate volatility, and a natural disaster. Specifically, the Financial Institutions Policy Committee imposed additional regulatory measures on housing loans to encourage prudent lending among financial institutions as the housing market buoyantly expanded in 2010 (Bank of Thailand 2003 and 2010). Credit-related regulatory measures had a minor impact on housing price appreciation, an insignificant effect on credit expansion, but an immediate impact on leverage growth.

\section{Taipei,China}

The economy has begun to pick up, but it and bank risk profiles remain hamstrung by high private leverage, excess capacity, and relatively sluggish prospects for small to medium-sized enterprises. The main challenge for the banks arises from the large existing stock of private credit at 165\% of GDP in 2012; about $50 \%$ of these loans are property-related. Mortgage debt accounts for nearly $80 \%$ of total property loans and has risen to levels where household debt servicing has become vulnerable to a shift in interest rates. ${ }^{12}$ Macroprudential measures have been moderately successful at best. Tighter LTV ratios and reserve requirements have been implemented to curb property market speculation and reduce credit growth.

\section{J. Philippines}

The latent propensity to macroprudential tightening features much of the Philippine Central Bank's (BSP) role in controlling excess liquidity in domestic financial markets by regularly tweaking liquidity reserve requirement ratios of banks and other banking institutions as needed. Despite the financial shocks brought about by the global economic slump in 2008, the Philippines continued to meet economic growth goals of $7.2 \%$ in 2007 and $4.6 \%$ in the succeeding year. Some changes ${ }^{13}$ will be fully implemented 2 years from their announcement by the BSP. With the BSP mulling a new LTV ratio for banking institutions to control bank lending, the impulse response function on the response of housing prices suggests a significant impact on its expansion. Liquidity-related macroprudential policies, on the other hand, seem to have a more significant impact on leverage growth, while credit growth is mitigated more by credit-related policies.

12 At $122 \%$ of disposable income, households are the most indebted in developing Asia with the exception of those in the Republic of Korea.

13 Recently, the BSP revealed that Philippine bank exposure to real estate had increased by $2.9 \%$ at the end of March 2014 compared to the end of December 2013. The Monetary Board, the major policy-making body of the BSP, approved major amendments to regulations governing credit-risk taking activities of banks and quasi-banks after a comprehensive policy review done by the BSP. Thus, the BSP announced major policy changes regarding the cap on bank lending to $60 \%$ of collateral value, down from $80 \%$ previously. 


\section{CONCLUDING OBSERVATIONS AND POLICY IMPLICATIONS}

There is a growing consensus in developing Asia and elsewhere that macroprudential policy measures could be useful for safeguarding financial stability, but their empirical effectiveness has not yet been well-established. We document three types of macroprudential policies-credit-related, liquidityrelated, and capital-related - that 10 economies in developing Asia have used and empirically examine their effectiveness in influencing three indicators of financial stability: credit growth, leverage growth, and housing price inflation. This paper innovates by utilizing the latent propensity to macroprudential policy to generate dynamic impulse responses of the three financial stability indicators to macroprudential policy.

Two significant findings emerge. Broadly, macroprudential policies can indeed promote financial stability in Asia. More specifically, different types of macroprudential policies are more effective against different types of macroeconomic risks. For example, the results suggest that creditrelated macroprudential policy dampened credit growth in India, liquidity-related policy reined in leverage growth in Indonesia, and credit-related policy helped to control housing price escalation in the Republic of Korea. The general pattern of the evidence from the 10 economies suggests that credit-related macroprudential policies can effectively dampen credit expansion and housing price inflation while liquidity-related macroprudential policy tools moderate leverage growth and housing price escalation. The salient implication for Asian financial regulators is that while they should explore the use of macroprudential policies, they should assess which specific policies are appropriate for the particular macroprudential risk they face.

Overall, our evidence indicates that macroprudential policies can be a valuable additional tool for Asia's financial regulatory authorities. The recent financial crises have shown that microprudential policy based on surveillance of individual financial institutions was not sufficient to safeguard the stability of the financial system. The crises also underscored the challenges associated with the interconnectedness of financial institutions and markets and global financial integration and revealed the costs of systemic instability. In order to prevent crisis and mitigate systemic risk, it is critically important for policy makers to detect undue risk accumulation and to identify emerging vulnerabilities and risks to financial stability. After detecting undue risk accumulation, policy makers should discourage excessive risk taking by providing appropriate incentives to financial market participants. They may also consider implementing macroprudential measures, especially those that have been effective in their own economies.

The global financial crisis has forced policy makers to review their policy frameworks, to examine how they could identify time-dimensional and cross-sectional risks in the finance sector, and to deal with those risks. Often procyclical systemic risk rises in tandem with cross-sectional systemic risk. Therefore, policy makers should be fully aware that time-dimensional risk during the peak of a financial cycle can trigger cross-sectional systemic risk that renders banks vulnerable to a common shock. Henceforth, in detecting systemic risks and tackling them, policy makers should avoid any complacency and should build a prudent and efficient macroprudential policy framework. At the same time, policy makers should realize that macroprudential policy alone may not be sufficiently effective in achieving financial stability; rather, a judicious mix of both microprudential and macroprudential policy instruments can be more effective than the stand-alone implementation of either. 


\section{REFERENCES}

Aiyar, S., C. Calomiris, and T. Wieladek. 2012. Does Macroprudential Leak? Evidence from a UK Policy Experiment. Bank of England Working Paper Series. No. 445. London: Bank of England.

Alberola, E., C. Trucharte, C., and J. L. Vega. 2011 Central Bank and Macroprudential Policy: Some Reflections from the Spanish Experience. Bank of Spain Occasional Paper Series. No. 1105. Madrid: Banco de España.

Bank of Indonesia. 2004. 2004 Economic Report on Indonesia. http://www.bi.go.id/en/publikasi/laporantahunan/perekonomian/Pages/lpi2004.aspx

-2009. 2009 Economic Report on Indonesia. http://www.bi.go.id/en/publikasi/laporantahunan/perekonomian/Pages/lpi_09.aspx

-2010. 2010 Economic Report on Indonesia. http://www.bi.go.id/en/publikasi/laporantahunan/perekonomian/Pages/Ipi_2010.aspx

Bank of Thailand. 2003 Payment Systems Report. https:/www.bot.or.th/English/PaymentSystems/ Publication/PS_Annually_Report/Documents/Payment_2003_E.pdf

—. 2010 Payment Systems Report. https://www.bot.or.th/English/PaymentSystems/Publication/ PS_Annually_Report/Documents/Payment_2010_E.pdf

Boissay, F., F. Collard, and F. Smets. 2013. Booms and Systemic Banking Crises. European Central Bank Working Paper Series. No. 1514. Frankfurt: European Central Bank.

Borio, C. 2010. The Financial Crisis: What Implications for New Statistics? Keynote speech delivered at the International Finance Corporation Fifth Conference, Initiatives to address data gaps revealed by the financial crisis. Basel. 25-26 August.

Christensen, I. and C. A. Meh. 2011. Countercyclical Loan-to-Value Ratios and Monetary Policy. Bank of Canada.

Christensen, I., C. A. Meh, and K. Moran. 2011. Bank Leverage Regulation and Macroeconomic Dynamics. Bank of Canada Working Paper Series. No. 2011-32. Ottawa: Bank of Canada.

Claessens, S., S. R. Ghosh, and R. Mihet. 2013. Macroprudential Policies to Mitigate Financial System Vulnerabilities. Journal of International Money and Finance. 39. pp. 153-85.

Crowe, C., G. Dell'Ariccia, D. Igan, and P. Rabanal. 2011. Policies for Macrofinancial Stability: Options to Deal with Real Estate Booms. IMF Staff Discussion Note No. SDN/11/02. Washington, DC: International Monetary Fund.

Dueker, M. 2005. Dynamic Forecasts of Qualitative Variables: A Qual VAR Model of US Recessions. Journal of Business and Economic Statistics. 23. pp. 96-104.

Economist Intelligence Unit (2014). Economy-specific quarterly data from 1999 to 2013. http://www.eiu.com/ (accessed 5 August 2014). 
Funke, M. and M. Paetz. 2013. A DSGE-based Assessment of Nonlinear Loan-to-Value Policies: Evidence from Hong Kong. BOFIT Discussion Paper Series. No. 11-2012. Helsinki: Bank of Finland, Institute for Economies in Transition.

Gelain, P., K. J. Lansing, and C. Mendicin. 2013. House Prices, Credit Growth and Excess Volatility: Implications for Monetary and Macroprudential Policy. International Journal of Central Banking. 9. pp. 219-76.

International Monetary Fund (IMF). International Financial Statistics (IFS). http://elibrarydata.imf.org/ (accessed 8 August 2014).

- 2012. The Interaction of Monetary and Macro-prudential Policies. Board Paper and Background Paper. January.

2013a. Key Aspects of Macro-prudential Policy-Background Paper (Policy Paper, June). http://www.imf.org/external/np/pp/eng/2013/061013C.pdf

—. 2013b. IMF Multilateral Policy Issues Report: 2013 Pilot External Sector Report. http://www.imf.org/external/np/pp/eng/2013/062013.pdf

Kawata, H., T. Kitamura, K. Nakamura, Y. Teranishi, and S. Tsuchiya. 2012. Effects of the Loss and Correction of a Reference Rate on Japan's Economy and Financial System: Analysis Using the Financial Macroeconometric Model. Bank of Japan Working Paper Series. No. 12-E-11. Tokyo: Bank of Japan.

Lim, C., F. Columba, A. Costa,P. Kongsamut, A. Otani, M. Saiyid, T. Wezel, and X. Wu. 2011. Macroprudential Policy: What Instruments and How to Use Them? Lessons from Country Experiences. IMF Working Paper Series. No. WP/11/238. Washington, DC: International Monetary Fund.

Lim, C., I. Krznar, F. Lipinsky, A. Otani, and X. Wu. 2013. The Macro-prudential Framework: Policy Responsiveness and Institutional Arrangements. IMF Working Paper Series. No. WP/13/166. Washington, DC: International Monetary Fund.

Meinusch, A. and P. Tillmann. 2014. The Macroeconomic Impact of Unconventional Monetary Policy Shocks. Joint Discussion Paper Series in Economics. No. 26-2014. Germany: Universities of Aachen, Gießen, Göttingen, Kassel, Marburg, and Siegen.

Shim, I., B. Bogdanova, J. Shek, and A. Subelyte. 2013. Database for Policy Actions on Housing Markets. Bank of International Settlements Quarterly Review. September.

Tillmann, P. 2014. Estimating the Effects of Macroprudential Policy Shocks. Center for Economic Research of Korea, Sungkyunkwan University, and the Korea Economic Research Institute.

Walentin, K. 2014. Housing Collateral and the Monetary Transmission Mechanism. The Scandinavian Journal of Economics. 116 (3). pp. 635-38. 
Wong, E., T. Fong, K. Li, and H. Choi. 2011. Loan-to-Value Ratio as a Macroprudential Tool-Hong Kong's Experience and Cross-country Evidence. HKMA Working Paper Series. No. 01/2011. Hong Kong, China: Hong Kong Monetary Authority.

Zhang, L. and E. Zoli. 2013. Leaning Against the Wind: Macroprudential Policy in Asia. IMF Working Paper Series. No. WP/14/22. Washington, DC: International Monetary Fund. 


\section{Effectiveness of Macroprudential Policies in Developing Asia: An Empirical Analysis}

The global financial crisis highlighted the need for improving national bank supervisory authorities' surveillance systems and detecting early on the buildup of macroeconomic risks. This paper presents an empirical framework for analyzing how effective macroprudential policies control credit, leverage, and housing price growth. Two findings emerge: (i) macroprudential policies can promote financial stability in Asia and (ii) different types of macroprudential policies are effective against different types of macroeconomic risks.

\section{About the Asian Development Bank}

ADB's vision is an Asia and Pacific region free of poverty. Its mission is to help its developing member countries reduce poverty and improve the quality of life of their people. Despite the region's many successes, it remains home to the majority of the world's poor. $A D B$ is committed to reducing poverty through inclusive economic growth, environmentally sustainable growth, and regional integration.

Based in Manila, ADB is owned by 67 members, including 48 from the region. Its main instruments for helping its developing member countries are policy dialogue, loans, equity investments, guarantees, grants, and technical assistance. 